\title{
Peningkatan Hasil Belajar Mengapresiasi Karya Seni Rupa Melalui Penggunaan Media Pembelajaran Appreciation Card Pada Mahasiswa Semester VIA, Mata Kuliah Pendidikan Keterampilan Seni Rupa Program PGSD di Stkip Taman Siswa Bima Tahun 2017
}

\author{
Sulfahri \\ STKIP Taman Siswa Bima \\ sulfahriadiwanhar@gmail.com
}

\begin{abstract}
ABSTRAK
Tujuan penelitian ini untuk meningkatkan hasil belajar dan aktivitas belajar Pada Mahasiswa Semester VI, Mata Kuliah Pendidikan Keterampilan Seni Rupa serta performansi Dosen dan calon guru pada materi mengapresiasi karya seni rupa melalui penggunaan media pembelajaran appreciation card untuk meningkatkan hasil belajar dan aktivitas belajar pada peserta didik. Jenis penelitian ini yaitu penelitian tindakan kelas yang dilaksanakan dalam dua siklus. Setiap siklus dilaksanakan melalui empat tahap, yaitu perencanaan, tindakan, pengamatan dan refleksi. Subjek yang diteliti yaitu mahasiswa Kelas IV A berjumlah 23 orang Program pendidikan guru sekolah dasar stkip taman siswa bima. Teknik pengumpulan data dilakukan melalui tes dan non tes (observasi dan dokumentasi). Indikator keberhasilan penelitian tindakan kelas ini yaitu ratarata kelas minimal 75, persentase tuntas belajar klasikal minimal $75 \%$, keberanian mahasiswa dalam mengajukan/menjawab pertanyaan Dosen $>=50 \%$, keterlibatan mahasiswa dalam kegiatan pembelajaran $>=75 \%$ dan skor performansi Dosen minimal 70. Hasil penelitian diperoleh persentase aktivitas belajar mahasiswa pada siklus I sebesar $75.70 \%$ dan meningkat menjadi $90.20 \%$ pada siklus II. Jadi persentase aktivitas belajar mengalami peningkatan sebesar $\mathbf{1 9 . 1 6 \%}$. Hasil belajar mahasiswa pada siklus I diperoleh ratarata kelas sebesar 59.58 dan meningkat menjadi 80.80 pada siklus II. Jadi rata-rata kelas mengalami peningkatan sebesar $35.62 \%$. Sedangkan persentase tuntas belajar klasikal pada siklus I sebesar $56.52 \%$ dan meningkat menjadi $86.96 \%$ pada siklus II. Jadi persentase tuntas belajar klasikal mengalami peningkatan sebesar 53.86\%. Performansi Dosen pada siklus I sebesar 83.85 dan meningkat menjadi 97.35. Jadi performansi Dosen mengalami peningkatan sebesar $16.10 \%$. Berdasarkan hasil penelitian tersebut, dapat disimpulkan bahwa penggunaan media pembelajaran appreciation card dapat meningkatkan aktivitas belajar mahasiswa, hasil belajar mahasiswa, dan performansi guru pada materi mengapresiasi karya seni rupa pada Kelas IVA STKIP Taman Siswa Bima. Oleh karena itu, sebaiknya Dosen menggunakan media pembelajaran appreciation card dalam pembelajaran mengapresiasi karya seni rupa.
\end{abstract}

Kata Kunci: meningkatkan hasil belajar dan aktivitas belajar

\section{PENDAHULUAN}

Undang-Undang Republik Indonesia Nomor 20 Tahun 2003 tentang Sistem Pendidikan Nasional dalam Bab I Pasal 1 Nomor 2 menyatakan bahwa "Pendidikan nasional adalah pendidikan yang berdasarkan Pancasila dan UndangUndang Dasar Negara Republik Indonesia Tahun 1945 yang berakar pada nilainilai agama, kebudayaan nasional Indonesia dan tanggap terhadap tuntutan perubahan zaman”. Pendidikan seni sekarang ini lebih berpusat pada proses, terutama untuk pendidikan dasar. Inilah tuntutan perubahan zaman bahwa pembelajaran supaya menekankan pada proses dari pada hasil, "...more importance on process than on the end product in early childhood education" (Stone dan Chakraborty). Muatan seni budaya dan keterampilan tidak hanya terdapat dalam satu 
mata pelajaran karena budaya itu sendiri meliputi segala aspek kehidupan. Dalam mata pelajaran Seni Budaya dan Keterampilan, aspek budaya tidak dibahas secara tersendiri tetapi terintegrasi dengan seni. Karena itu, mata pelajaran Seni Budaya dan Keterampilan pada dasarnya merupakan pendidikan seni yang berbasis budaya. Pendidikan Seni Budaya dan Keterampilan diberikan di sekolah karena keunikan, kebermaknaan, dan kebermanfaatan terhadap kebutuhan perkembangan peserta didik, yang terletak pada pemberian pengalaman estetik 2 dalam bentuk kegiatan berekspresi/berkreasi dan berapresiasi. Dalam Peraturan Pemerintah Nomor 19 Tahun 2005 Tentang Standar Nasional Pendidikan Pasal 6 Ayat (1) butir d disebutkan bahwa kelompok mata pelajaran estetika atau bentuk lain yang sederajat dimaksudkan untuk meningkatkan sensitifitas, kemampuan mengekspresikan dan kemampuan mengapresiasi keindahan dan harmoni. Kemampuan mengapresiasi dan kemampuan mengekspresikan keindahan serta harmoni mencakup apresiasi dan ekspresi, baik dalam kehidupan individual sehingga mampu menikmati dan menyukuri hidup, maupun dalam kehidupan kemasyarakatan sehingga mampu menciptakan kebersamaan yang harmonis.

Mata Kuliah pendidikan keterampilan seni rupa masih dipahami sebagai mata pelajaran yang membuat suatu karya seni atau dalam istilah seni disebut kreasi. Mahasiswa merespon kedatangan Dosen yang akan mengajar mata pelajaran SBK (pendidikan keterampilan seni rupa) dengan persiapan segala perlengkapan seninya untuk membuat gambar.

Itulah yang dialami peneliti ketika akan mengajarkan pelajaran pendidikan keterampilan seni rupa. Padahal pelajaran SBK juga mengajarkan kepada siswa mengenai bagaimana memberi penghargaan terhadap suatu karya seni atau dalam istilah seni disebut apresiasi. Kegiatan apresiasi merupakan kegiatan yang tidak lepas dari kehidupan manusia, seperti menikmati dan merasakan nilai-nilai yang ada pada karya orang lain yang diwujudkan dalam berbagai bentuk. Apresiasi berperan sebagai bentuk penghargaan pengamat terhadap keunikan karya dari seniman yang bisa berupa rasa senang atau tidak senang, dapat juga beranggapan baik ataupun tidak baik. Apresiasi diperlukan agar manusia mampu memahami suatu karya seni dengan 3 baik. Kegiatan apresiasi merupakan hal yang sangat penting dalam pendidikan seni rupa, karena dengan apresiasi, siswa akan melihat keindahan suatu karya seni. Hal ini merupakan kegiatan mental yang kreatif. Apresiasi dikatakan sebagai suatu sikap dalam hal mencermati dan memahami seni. Sikap bukanlah sesuatu yang dapat tumbuh secara tiba-tiba, tetapi sikap hanya dapat tumbuh melalui kegiatan yang berulang-ulang. Apresiasi sebagai bagian dalam pendidikan seni rupa merupakan hal yang sangat penting untuk diberikan kepada mahasiswa, yang berguna untuk mengembangkan kemampuan atau pengetahuannya terhadap karya seni, sebagaimana diungkapkan oleh Read (dalam Soebandi, 2008: 116) yang menyatakan bahwa seni sebagai bagian dari wilayah pembelajaran perlu dikembangkan melalui pembelajaran apresiasi. Bagi mahasiswa, biasanya kegiatan apresiasi ini berfungsi untuk menumbuhkan atau memupuk rasa cinta terhadap budaya bangsa dan membuka cakrawala mahasiswa. Dengan memperkenalkan hasil karya seni tersebut, mahasiswa akan mulai mengenali budaya bangsa tersebut dari jenis, bahan, dan cara membuatnya. Untuk itu, dalam pembelajaran mengapresiasi karya seni rupa ini guru harus memiliki kemampuan dalam menggunakan bahan pembelajaran yang efektif dan efisien. Pembelajaran mengapresiasi karya seni rupa perlu adanya media pembelajaran yang inovatif, kreatif, dan interaktif agar siswa dapat mengapresiasi karya seni rupa dengan lebih mudah. Pemilihan media pembelajaran bukanlah hal yang sulit, jika guru dapat memahami karakteristik siswa dan bahan ajar yang hendak disampaikan. Kemampuan guru dalam memilih, mengeksplorasi, dan 4 menggunakan media pembelajaran yang diterapkan dalam pembelajaran perlu dimiliki dan dikembangkan. Media pembelajaran berfungsi sebagai alat bantu siswa dalam 
memahami bahan ajar dan memfasilitasi siswa melakukan kegiatan pembelajaran, sehingga siswa memperoleh pengalaman belajar dan hasil belajar yang diinginkan dapat tercapai dengan baik. Oleh karena itu, guru perlu memberikan media sehingga media merupakan strategi yang sangat penting untuk menumbuhkan motivasi siswa dan akan lebih mudah dalam mengapresiasi karya seni rupa. Terdapat suatu media yang pernah digunakan dalam pembelajaran mengapresiasi karya seni rupa. Media bernama appreciation card diciptakan oleh Eko Sugiarto, seorang mahasiswa Pendidikan Seni Rupa di Stkip Taman Siswa Bima. Melalui penggunaan media tersebut, hasil belajar mengapresiasi karya seni rupa dapat ditingkatkan. Hasil pembelajaran Seni Budaya dan Keterampilan di kelas Mahasiswa Semester VIA, Mata Kuliah Pendidikan Keterampilan Seni Rupa Program PGSD Di Stkip Taman Siswa Bima khususnya materi apresiasi seni rupa kurang memuaskan. Hal ini ditunjukkan dengan perolehan hasil belajar Mahasiswa yang belum memuaskan, masih terdapat beberapa nilai Mahasiswa yang belum memenuhi Kriteria Ketuntasan Minimal (KKM). Nilai KKM mata pelajaran Seni Budaya dan Keterampilan (SBK) di SD Kraton 2 Kota Tegal yaitu 71. Dari sejumlah 16 orang Mahasiswa terdapat 6 (enam) orang Mahasiswa yang memperoleh nilai dibawah 71. Hal ini dikarenakan beberapa faktor penyebab baik faktor internal yang datang dari dalam Mahasiswa sendiri seperti kurangnya motivasi dalam diri Mahasiswa dalam mengikuti pelajaran maupun eksternal yang datang dari guru misalnya penggunaan media yang kurang menarik. 5 Penelitian tindakan kelas ini dipilih karena pembelajaran seni rupa selama ini tidak memanfaatkan media yang inovatif, kreatif dan interaktif. Hasil penelitian ini diharapkan memberi sumbangan pikiran untuk menunjang keberhasilan pembelajaran mengapresiasi karya seni rupa di Mahasiswa kelas Semester VIA, Mata Kuliah Pendidikan Keterampilan Seni Rupa Program PGSD. Berdasarkan latar belakang dan perumusan masalah di atas, peneliti akan menggunakan media pembelajaran appreciation card untuk meningkatkan kualitas pembelajaran mengapresiasi karya seni rupa pada kelas Mahasiswa Semester VIA, Mata Kuliah Pendidikan Keterampilan Seni Rupa Program PGSD Di Stkip Taman Siswa Bima: (1) Meningkatkan aktivitas belajar mengapresiasi karya seni rupa melalui penggunaan media pembelajaran appreciation card pada mahasiswa Kelas VIA Program PGSD Stkip Taman Siswa Bima. (2) Meningkatkan hasil belajar mengapresiasi karya seni rupa melalui penggunaan media pembelajaran appreciation card pada mahasiswa Kelas VIA Program PGSD Stkip Taman Siswa Bima. (3) Meningkatkan performansi guru dalam pembelajaran mengapresiasi karya seni rupa melalui penggunaan media pembelajaran appreciation card pada Mahasiswa VIA Program PGSD Stkip Taman Siswa Bima.

\section{Prestasi dan aktivitas belajar}

Aktivitas Belajar Menurut Kamus Besar Bahasa Indonesia, aktivitas artinya kegiatan, keaktifan, kesibukan. Belajar menurut Dimyati dan Mudjiono (1999: 7) merupakan tindakan dan perilaku siswa yang kompleks. Menurut Sardiman dalam Saminanto (2010: 97) aktivitas belajar adalah keaktifan yang bersifat fisik maupun mental. Aktivitas yang dimaksudkan disini penekanannya pada siswa, 11 sebab dengan adanya aktivitas siswa dalam proses pembelajaran akan berdampak terciptanya situasi belajar aktif. Karena aktivitas tersebut sangat bermanfaat bagi peserta didik dalam mencari pengalaman dan mengalami sendiri, sehingga pembelajaran lebih berhasil dan menarik. Menurut Dimyati dan Mudjiono (1999: 51), implikasi keaktifan bagi siswa berwujud perilaku-perilaku seperti mencari sumber informasi yang dibutuhkan, menganalisis hasil percobaan, ingin tahu hasil dari suatu reaksi kimia, membuat karya tulis, membuat kliping dan perilaku sejenis lainya. Jadi, dapat disimpulkan bahwa aktivitas belajar merupakan kegiatan fisik maupun mental yang mendukung siswa belajar sehingga tercipta situasi belajar yang aktif. 2.1.3 Hasil Belajar Keberhasilan dari proses pembelajaran dapat diukur dari seberapa jauh hasil belajar yang dicapai siswa. Menurut Catharina Tri Anni, dkk. 
(2007: 5), hasil belajar merupakan perubahan perilaku yang diperoleh pembelajar setelah mengalami aktivitas belajar. Suprijono dalam Thobroni dan Mustofa (2011: 22) merumuskan hasil belajar adalah pola-pola perbuatan, nilainilai, pengertian pengertian, sikap-sikap, apresiasi, dan keterampilan. Hasil belajar siswa akan terlihat adanya perubahan perilaku setelah melakukan aktivitas belajar berupa nilai, pengertian, sikap, apresiasi, keterampilan dan perbuatan. Dari hasil belajar siswa itulah dapat diketahui seberapa jauh tujuan pembelajaran telah dicapai. Bloom dalam Anni, dkk. (2007: 7) merumuskan hasil belajar sebagai perubahan tingkah laku yang mengusulkan tiga taksonomi yang disebut dengan ranah belajar, yaitu ranah kognitif, ranah afektif, dan ranah psikomotorik. Ranah 12 kognitif yang mencakup ranah pengetahuan, ranah afektif mencakup ranah sikap dan ranah psikomotor mencakup ranah keterampilan. Dengan demikian dapat disimpulkan bahwa hasil belajar merupakan suatu kemampuan atau keterampilan yang dimiliki oleh siswa setelah siswa tersebut mengalami aktivitas belajar yang mencakup tiga ranah belajar yakni kognitif, afektif dan psikomotor.

Mata Pelajaran Seni Budaya dan Keterampilan Kurikulum pendidikan di Indonesia memasukkan pendidikan seni dalam mata pelajaran Seni Budaya dan Keterampilan. Kemudian pendidikan seni dibagi menjadi beberapa bidang seni. 2.1.5.1 Pendidikan Seni Istilah umum pendidikan seni terdiri dari mata pelajaran tari, drama, musik, media, dan seni rupa, sebagaimana pernyataan "given that the umbrella term 'art education' now collect the school subject dance, drama, music, media, and visual art 'visuasi' might serve to distinguish what visual arts uniquely provides among the range of subjects that have, in effect, been put into competition in our schools" (Lee, 2009: 218). 14 Pendidikan seni di sekolah dasar tercantum dalam Kurikulum Tingkat Satuan Pendidikan (KTSP) tahun 2006 dengan sebutan Seni Budaya dan Keterampilan (SBK). Bambang Soehendro (2006: 186) menyatakan bahwa mata pelajaran Seni Budaya dan Keterampilan bertujuan agar peserta didik memiliki kemampuan memahami konsep dan pentingnya seni budaya dan keterampilan, menampilkan sikap apresiasi terhadap seni budaya dan keterampilan, menampilkan kreativitas melalui seni budaya dan keterampilan, menampilkan peran serta dalam seni budaya dan keterampilan dalam tingkat lokal, regional, maupun global. Mata pelajaran Seni Budaya dan Keterampilan meliputi aspek seni rupa, seni musik, seni tari, seni drama, dan keterampilan. Seni rupa mencakup pengetahuan, keterampilan, dan nilai dalam menghasilkan karya seni berupa lukisan, patung, ukiran, cetak-mencetak, dan sebagainya. Seni musik, mencakup kemampuan untuk menguasai olah vokal, memainkan alat musik, apresiasi karya musik. Seni tari, mencakup keterampilan gerak berdasarkan olah tubuh dengan dan tanpa rangsangan bunyi, apresiasi terhadap gerak tari. Seni drama, mencakup keterampilan pementasan dengan memadukan seni musik, seni tari dan peran. Keterampilan, mencakup segala aspek kecakapan hidup (life skills) yang meliputi keterampilan personal, keterampilan sosial, keterampilan vokasional dan keterampilan akademik. 2.1.5.2 Seni Rupa Kamaril (2007: 1.5) menyatakan bahwa seni adalah estetika, estetika adalah keindahan. Menurut Hiusman dalam Sahman (1993: 11) menjelaskan seni 15 itu dapat dikonsepsi antara lain sebagai kegiatan meniru alam, kegiatan bermainmain dengan bentuk seni. Seni lahir sebagai sarana pemenuhan keinginankeinginan bawah sadar. Sedangkan Pamadhi (2010: 1.4) menyatakan pula bahwa seni adalah ekspresi jiwa manusia yang tertuang dalam berbagai bentuk karya seni. Karya seni merupakan perwujudan terselubung dari keinginan bawah sadar itu. Kamaril (2007: 2.5) menjelaskan bahwa seni rupa adalah bentuk ungkapan yang dinyatakan melalui media rupa. Dapat dikatakan bahwa seni rupa adalah bentuk ungkapan yang dicurahkan melalui media rupa (visual) menjadi karya dwimatra dan trimatra. Kamaril (20017: 2.10) menjabarkan jenis karya seni rupa antara lain, gambar/lukisan, seni grafis, seni patung, keramik, dan seni rupa terapan. Gambar/lukisan merupakan jenis karya seni rupa dwimatra. 
Menggambar merupakan proses perekaman objek ke dalam bidang dua dimensi. Sedangkan seni lukis cenderung mengekspresikan konseptual seniman melalui media ungkap dan teknik berdasarkan prinsip-prinsip seni rupa. Seni grafis adalah salah satu bagian seni rupa dwimatra yang berusaha menghasilkan karya seni rupa yang bersifat dapat diperbanyak. Seni patung adalah bagian seni rupa yang merupakan pernyataan pengalaman artistik manusia melalui bentuk-bentuk trimatra. Keramik sering diidentikkan dengan seni terapan, karena pada umumnya karya-karya keramik tampil dengan bentuk guci dan perlengkapan rumah tangga. Seni rupa terapan dapat dibedakan menjadi dua bagian, yakni seni kriya dan desain. Seni kriya biasanya dibuat dengan dibuat dengan tujuan untuk 16 melestarikan tradisi berkesenirupaan suatu daerah atau suatu bangsa. Sedangkan desain diciptakan dengan tujuan untuk memenuhi kebutuhan konsumen akan produkproduk seni. 2.1.6 Konsep Dasar Apresiasi Seni Apresiasi termasuk dalam materi pendidikan seni diantara dua materi seni lainnya. Hal ini sebagaimana yang disebutkan oleh Soebandi (2008: 44) bahwa ada 3 (tiga) cakupan substansi materi yang dipelajari dari pendidikan seni, yaitu konsepsi, kreasi dan apresiasi. Pembelajaran konsepsi dilakukan untuk membekali siswa mengetahui materi ilmu seni, kegiatan berolah seni dilakukan untuk memberikan pengalaman dan kemahiran mencipta seni, dan berapresiasi seni dilakukan untuk memberi pengalaman dalam proses menghargai karya seni. 2.1.6.1 Pengertian Apresiasi Apresiasi merupakan kegiatan mental individu dalam proses penilaian. Pandangan lain mengenai istilah ini ditunjukkan kepada khalayak sebagai pertukaran pikiran yang berhubungan dengan mengagumi sesuatu nilai. Menurut Soebandi (2008: 104) apresiasi seni berarti pengertian yang sebenarnya mengenai seluk-beluk sesuatu hasil seni serta menjadi sensitif terhadap segi-segi estetika. Masih dalam pengertian yang sama, kemudian Bastomi (2003: 29) menambahkan dengan apresiasi kita mampu menikmati dan menilai karya seni dengan semestinya. Jika ditinjau dari asal katanya, apresiasi berasal dari kata appreciation. Dalam bentuk kata kerjanya yaitu to appreciate yang berarti menentukan nilai, mengerti atau menikmati sepenuhnya dengan jalan benar. Selanjutnya Bastomi 17 (2003: 28) mendefinisikan apresiasi adalah suatu aktivitas dalam rangka menikmati, merasakan nilai-nilai yang ada pada suatu karya seni dengan terlebih dahulu oleh minat estetik. Hal ini diperkuat oleh Paper (dalam Bastomi, 2003: 28) yang mengemukakan bahwa apresiasi pada dasarnya menyenangi sesuatu barang agar memperoleh pengalaman yang menyenangkan. Pernyataan lain juga dikemukakan oleh Bahari (2008: 148) yang mengemukakan bahwa apresiasi merupakan proses sadar yang dilakukan oleh seseorang dalam menghadapi dan memahami karya seni. dalam memahami karya seni sebaiknya terlebih dahulu mengenal struktur bentuk karya seni, pengorganisasian elemen seni rupa atau dasardasar penyusunan dari karya seni yang sedang diapresiasi. Kemudian dalam mengapresiasi proses yang terjadi yaitu proses menafsirkan sebuah makna yang terkandung dalam karya seni. Sudarso (dalam Bastomi, 2003: 28) menuliskan bahwa apresiasi berarti mengerti serta menyadari sepenuhnya sehingga mampu menilai semestinya, sedangkan dalam hubungannya dengan seni menjadi: mengerti dan menyadari sepenuhnya seluk beluk sesuatu hasil seni serta menjadi sensitif terhadap segi-segi estetiknya, sehingga mampu menikmati dan menilai karya seni rupa dengan semestinya. Dengan demikian dapat dinyatakan bahwa apresiasi merupakan proses pengenalan nilainilai seni untuk menghargai dan menafsirkan makna (arti) yang terkandung di dalam karya seni rupa melalui kegiatan pengamatan yang menimbulkan respon terhadap stimulus yang berasal dari karya seni, sehingga 18 menimbulkan rasa keterpesonaan yang diikuti dengan penikmatan serta pemahaman bagi pengamatnya. 2.1.6.2 Dimensi Apresiasi Menurut Osborn (dalam Sobandi, 2008: 108) membagi apresiasi menjadi dua dimensi yaitu, apresiasi sebagai suatu sikap (attitudes) dan apresiasi sebagai suatu aksi (actions). Apresiasi sebagai suatu sikap sering didefinisikan sebagai suatu kebiasaan (habits) dan keahlian (skills), 
tetapi apresiasi seharusnya mengandung suatu sikap atau perasaan tentang seni yang membawa individu kepada suatu pengalaman tentang seni. Apresiasi dapat mengembangkan kebiasaan mental berupa perhatian (attentions) dan ketertarikan (interest) secara bersama-sama membawanya dengan keahlian yang dituntut dalam keahlian dan kemampuan yang tumbuh dari pengulangan dan perhatian dari pengalaman. Jadi dapat dikatakan bahwa apresiasi sebagai suatu sikap dapat tumbuh dari pengulangan dan perhatian dari pengalaman yang dapat diperdalam melalui setudi secara formal. Apresiasi sebagai suatu aksi dapat dilatih melalui kegiatan apresiasi. Kegiatan ini meliputi bagaimana seorang apresiator melakukan pengamatan dengan memusatkan perhatian, mengenal perbedaan meningkatkan pemahaman kontekstual dan penilaian. Apresiator harus terlibat aktif dalam kegiatan apresiasi seni dalam kehidupan sehari-hari. Keterampilan apresiasi seni dikembangkan atas dasar pengetahuan yang dimiliki apresiator dalam melakukan kegiatan apresiasi. Apresiasi seni berlangsung alamiah dalam bentuk kegiatan interaksi antara apresiator dengan 19 karya seni. Agar proses hubungan tersebut berjalan dengan lancar, aktif dan komunikatif, maka sejumlah wawasan yang berkaitan dengan pemahaman tentang seni harus dikuasai dengan baik. Seorang siswa yang menjadi apresiator karya seni dapat dikatakan bahwa apresiasi yang dilakukan siswa tersebut termasuk apresiasi sebagai suatu aksi. Apresiasi yang dilakukan oleh siswa terhadap karya seni terdiri dari beberapa kegiatan apresiasi yang saling berkaitan sehingga kegiatan-kegiatan apresiasi tersebut mengantarkan siswa dalam mengapresiasi karya seni. 2.1.6.3 Proses Apresiasi Garha (1980: 58) menjelaskan bahwa kegiatan apresiatif ialah kegiatan penghayatan seni yang didalamnya termasuk aktivitas mental yang berupa penikmatan, pengaguman serta penilaian. Menurut Syafii (dalam Sugiarto, 2011: 2) proses apresiasi seni rupa dapat diawali dengan kegiatan melihat, mengamati, menghayati, dan selanjutnya memasuki proses menilai dan menghargai. Melihat adalah kegiatan yang paling awal dilakukan oleh pengamat. Selanjutnya, melalui penginderaan tersebut pengamat mulai memasuki proses psikologis lebih dalam yang disebut dengan penghayatan. Dalam proses inilah apresiator mulai memahami karya seni, yang dilanjutkan dengan proses penilaian dan penghargaan. Penilaian dan penghargaan merupakan pengambilan keputusan dengan pertimbanganpertimbangan tertentu yang bernilai atau berharga. Dalam proses inilah apresiator mulai menentukan keputusan apakah suka/tidak suka, indah/tidak indah, cocok/tidak cocok dengan suasana hatinya. 20 Berdasarkan uraian di atas, proses apresiasi seni dapat berupa kegiatan: melihat sepenuhnya karya seni, mengamati dengan seksama suatu karya, menghayati maksud yang terkandung dalam karya, serta menilai dan menghargai karya. Aktivitas apresiasi dapat dilakukan secara langsung berhadapan dengan karya seni rupa yang ada pada pameran, museum, studio, galeri, dan pusat-pusat seni/kerajinan itu dibuat. Aktivitas apresiasi dapat juga dilakukan dengan mengamati objek secara tidak langsung melalui gambar pada buku, foto, slide, film, atau sumber lain. 2.1.6.4 Apresiasi Seni dalam Konteks Pendidikan Menurut Kartono (dalam Soebandi, 2008: 111) apresiasi adalah suatu proses yang melahirkan sikap dalam mencermati seni. Sikap adalah sesuatu yang tidak tumbuh dengan begitu saja. Sikap terbentuk setelah berulang-ulang. Sikap (attitude) adalah kecenderungan untuk memberi respon, baik positif maupun negatif, terhadap orang-orang, benda-benda, situasi-situasi tertentu. Berdasarkan hal tersebut, agar kemampuan apresiasi tumbuh, maka dapat melalui proses pendidikan seperti pendidikan seni. Upaya ini sangat strategis dalam membina siswa untuk dapat menghayati, menikmati, menghargai, serta menilai karya seni. Melalui kegiatan ini diharapkan peserta didik sebagai generasi penerus bangsa mampu memiliki kecintaan untuk menghargai kaya-karya seni dan budaya bangsa dimasa yang akan datang. 


\section{METODE}

\section{Pendekatan Penelitian}

Jenis penelitian ini yaitu Penelitian Tindakan Kelas (PTK) atau Classroom Action Research (CAR). Suharsimi Arikunto, dkk. (2009: 3) mengartikan bahwa penelitian tindakan kelas merupakan suatu pencermatan terhadap kegiatan belajar berupa sebuah tindakan, yang sengaja dimunculkan dan terjadi dalam sebuah kelas secara bersama. Suharsimi Arikunto, dkk. (2009: 16) menjelaskan bahwa dalam penelitian ini terdiri dari empat tahapan yang dilalui, yaitu
(1) perencanaan,
(2) pelaksanaan,

pengamatan dan (4) refleksi. Keempat tahap dalam penelitian tindakan tersebut adalah unsur untuk membentuk sebuah siklus, yaitu satu putaran kegiatan beruntun, yang kembali ke langkah semula. Penelitian ini dilaksanakan dalam dua siklus. Siklus I dilaksanakan selama dua pertemuan, siklus II dilaksanakan selama dua pertemuan. Setiap pertemuan terdiri dari dua jam pelajaran.

\section{Perencanaan Tahap Penelitian Penelitian}

Ini direncanakan minimal dalam dua siklus dengan berbagai kemungkinan perubahan yang dianggap penting sehingga terdapat perencanaan tahap penelitian siklus I dan perencanaan tahap penelitian siklus II. 28 Setiap siklus terdiri dari 4 tahap, yaitu perencanaan, pelaksanaan, pengamatan, dan refleksi. (1) Perencanaan Pada tahap ini peneliti menyusun rancangan tindakan yang akan dilakukan dalam penelitian. Peneliti melaksanakan prasurvei, menemukan dan menganalisis masalah sehingga peneliti dapat merumuskan dan mengembangkan alternatif tindakan untuk dapat memperbaiki hasil belajar siswa. Peneliti menyusun rancangan strategi dan skenario penerapan pembelajaran yang akan diterapkan. Instrumen penelitian disiapkan sebelum pelaksanaan penelitian. (2) Pelaksanaan Pada tahap ini peneliti melaksanakan penelitian sesuai dengan perencanaan, mengumpulkan dan merekam data dengan menggunakan instrumen penelitian yang telah disiapkan. (3) Pengamatan Pada tahap ini peneliti melakukan pengamatan/observasi berjalan bersamaan pelaksanaan tindakan. Pengamatan dilakukan oleh peneliti untuk mengumpulkan data kualitatif dengan menggunakan instrumen lembar pengamatan. Peneliti juga mencatat semua hal yang diperlukan dan terjadi selama pelaksanaan tindakan berlangsung. (4) Refleksi Pada tahap ini peneliti mengkaji secara menyeluruh tindakan yang telah dilakukan, berdasarkan data yang telah terkumpul, kemudian dilakukan evaluasi guna menyempurnakan tindakan berikutnya. Peneliti mengevaluasi hasil belajar 29 dan aktivitas belajar siswa.

\section{Waktu Penelitian}

Waktu penelitian direncanakan selama satu tahun yang dimulai pada bulan November 2016 sampai dengan September 2017.

\section{Pengumpulan Data}

Dalam pengambilan data digunakan beberapa teknik antara lain:

Tes

Tes digunakan untuk mengukur hasil belajar mahasiswa pada akhir setiap siklus. Jenis tes yang digunakan adalah tes tertulis dan bentuk tes yaitu pilihan ganda dan isian singkat. Tes pilihan ganda berisi soal-soal untuk mengukur tingkat pemahaman mahasiswa terhadap materi karya seni rupa. Tes isian singkat berisi soalsoal untuk mengukur kemampuan mahasiswa dalam mengapresiasi karya seni rupa menggunakan appreciation card.

Observasi

Observasi digunakan untuk memperoleh data aktivitas belajar siswa dan performansi guru.

\section{Dokumentasi}

Dokumentasi menurut Sugiyono (Mariamah, dkk: 2016) merupakan kegiatan mencari data mengenai hal- hal atau variabel yang berupa catatan, transkrip, buku, surat kabar, majalah, prasati, notulen rapat, lengger, agenda dan sebagainya digunakan sebagai bukti pelaksanaan pembelajaran dalam penelitian. Dokumentasi dalam penelitian ini berupa daftar nama Mahasiswa, daftar nilai Mahasiswa dan foto-foto aktivitas Mahasiswa dalam pembelajaran mengapresiasi karya seni rupa melalui penggunaan media pembelajaran appreciation card di kelas A Semester VI Program pendidkikan Guru Sekolah Dasar di STKIP TAMAN SISWA BIMA. 


\section{Teknik Analisa Data}

Data penelitian terdiri dari data kuantitatif dan data kualitatif. Jadi teknis analisis data dalam penelitian ini yaitu dengan teknik analisis data kuantitatif dan teknik analisis data kualitatif.

Untuk menentukan nilai akhir hasil belajar yang diperoleh masing-masing siswa dari tes. Nilai Akhir $=$ Skor Perolehan $\mathrm{x} 100$ Skor Maksimal (BSNP, 2007: 25) (2) Untuk menentukan rata-rata kelas $\mathrm{M}=\sum \mathrm{X} \quad \mathrm{N} 36$ Keterangan: $\mathrm{X}=$ Nilai yang diperoleh individu $\mathrm{N}$ = Banyaknya individu M = Nilai Rata-rata kelas (Sudjana, 2010: 125) (3) Untuk menentukan tuntas belajar klasikal $\mathrm{p}=$ Jumlah mahasiswa yang tuntas belajar x 100\% Jumlah mahasiswa Keterangan: $\mathrm{p}=$ Tuntas belajar klasikal Kriteria Tingkat Keberhasilan Belajar Siswa: $>80 \%=$ Sangat tinggi $60-79 \%=$ Tinggi $40-59 \%=$ Sedang $20-39 \%=$ Rendah

\section{HASIL PENELITIAN}

\section{Hasil Penelitian}

Analisis Deskriptif Data Penelitian Populasi dalam penelitian ini adalah mahasiswa kelas IVA Program pendidikan guru sekolah dasar, STKIP Taman Siswa Bima, kecamatan palibelo kabupaten bima tahun Pelajaran 20167sebanyak 225 mahasiswa dengan sampel sebanyak 90 mahasiswa. Untuk memperoleh gambaran tentang karakteristik setiap variabel, maka digunakan analisis statistik deskriptif. Berikut ini akan disajikan deskripsi data hasil penelitian yang terdiri dari dua variabel, yaitu penguasaan kosakata sebagai variabel bebas, dan kemampuan membaca pemahaman sebagai variabel terikat. 4.1.1.1 Variabel Penguasaan Kosakata Data penguasaan kosakata diperoleh melalui tes penguasaan kosakata yang terdiri dari 25 item soal pilihan ganda dengan skor benar 1 dan skor salah 0. Kemudian jumlah skor yang diperoleh dikalikan 4. Sehingga diperoleh skor total tertinggi 100 dan skor total terendah 0 . Skor tertinggi yang diperoleh dari data adalah 92, dan skor terendah yang diperoleh dari data adalah 32. Berdasarkan data tersebut diperoleh juga rata-rata $(\mathrm{M})$ sebesar 65,6, median $(\mathrm{Md})$ sebesar 66, dan modus (Mo) sebesar 64 serta simpangan baku 14,4. Untuk menentukan jumlah kelas interval digunakan rumus Sturges (Sugiyono,2012:34), yaitu jumlah kelas $=1+3,3$ $\log \mathrm{n}$, dimana $\mathrm{n}$ adalah jumlah sampel atau responden. Dari perhitungan diketahui bahwa $n$ $=90$, sehingga 71 diperoleh banyak kelas $1+3,3$ $\log 144=7,5$ dibulatkan menjadi 8 kelas interval. Rentang data dihitung dengan rumus nilai maksimal - nilai minimal kemudian ditambah 1, sehingga diperoleh rentang data sebesar $(92-32)+1=61$, sedangkan panjang kelas (rentang) $/ \mathrm{K}=(61) / 8=7,6$.

Rata-rata hasil belajar mahasiswa pada siklus I diperoleh 59.58 dengan ketuntasan belajar 56.52, dari hasil belajar tersebut dapat dikatakan bahwa nilai hasil belajar mahasiswa masih sangat rendah dan tidak mencapai target indikator keberhasilan yang ditetapkan. Upaya untuk memperbaiki kondisi tersebut dapat diatasi dengan membuat instrumen penelitian yang lebih efektif. Tes formatif Rata-rata Tuntas belajar Aktivitas siswa Performansi guru 01020 30405060708090 Indikator yang ditentukan Hasil penelitian Tuntas belajar Tidak tuntas belajar 48 siklus I tidak lebih banyak menunjukkan gambar maka guru dapat membuat tes formatif untuk siklus II dengan lebih banyak pilihan jawaban bergambar bukan selalu dengan tulisan saja sehingga siswa lebih antusias dalam mengerjakan tes. Pada silabus terdapat kegiatan yang belum dilaksanakan pada siklus I yaitu membuat produk karya seni rupa berupa gambar motif batik. Hal ini merupakan tantangan bagi guru untuk mempersiapkan kegiatan kreasi dan apresiasi supaya dapat terlaksana pada siklus II. Guru dapat memodifikasi appreciation card yang bisa digunakan untuk berkreasi sekaligus dapat diapresiasi oleh siswa. Namun perlu diperhatikan kegiatan pembelajaran dengan alokasi waktu pelajaran yang tersedia. Persentase aktivitas belajar siswa pada siklus I diperoleh 75.70\% maka aktivitas belajar siswa sudah memenuhi indikator kerbehasilan. Pada siklus I, siswa belum diberikan kesempatan untuk berkreasi membuat karya seni rupa. Kegiatan berkreasi dan mengapresiasi dilaksanakan pada siklus II merupakan kesempatan bagi guru untuk 
meningkatkan aktivitas belajar siswa. Persentase performansi guru pada siklus I diperoleh 83.85 maka performansi guru sudah memenuhi indikator keberhasilan. Guru perlu mencantumkan dampak pengiring pada RPP dan penggunaan media lain selain media appreciation card. 4.1.2 Deskripsi Data Pelaksanaan Tindakan Siklus II Siklus II dimulai pada pertemuan ketiga pada hari Sabtu tanggal 19 Mei 2012. Karena pada siklus I hasil belajar masih belum mencapai indikator keberhasilan keberhasilan maka pembelajaran mengapresiasi karya seni rupa 49 diulang dengan perubahan kegiatan pembelajaran dan modifikasi Appreciation Card. Materi pada siklus II sama dengan materi pada siklus I. Pada pertemuan ketiga siswa belajar tentang seni rupa murni dan seni rupa terapan. Guru menggunakan metode ceramah dan media pembelajaran Appreciation Card. Siswa dengan kelompoknya memanfaatkan Appreciation Card untuk lebih mendalami contoh-contoh karya seni rupa. Guru juga mengenalkan motif batik. Di akhir pertemuan ketiga siswa mengerjakan soal-soal latihan. Pertemuan keempat dilaksanakan pada hari Rabu tanggal 23 Mei 2012. Masing-masing siswa membuat gambar motif batik kemudian diapresiasi. Guru menggunakan metode ceramah dan media Appreciation Card. Siswa menggambar motif batik seperti yang sudah dikenalkan pada pertemuan-pertemuan sebelumnya. Siswa menggambar motif batik dengan teknik jiplakan. Gambar jiplakan motif batik dibagikan kepada setiap siswa. Setiap siswa disediakan pilihan dua gambar jiplakan. Setiap siswa memilih sendiri motif yang diinginkannya. Setelah selesai menggambar, masing-masing siswa saling bertukar gambar satu sama lain kemudian setiap siswa mengapresiasi gambar temannya.

Jumlah siswa yang sudah tuntas atau mencapai nilai $>=71$ sebanyak 20 siswa, sedangkan siswa yang belum tuntas sebanyak 2 siswa, sehingga persentase tuntas belajar klasikal $86,96 \%$.

Deskripsi Observasi Proses Pembelajaran

Deskripsi observasi pembelajaran terdiri dari hasil pengamatan terhadap aktivitas mahasiswa dan performansi guru. 4.1.1.2.1 Deskripsi Aktivitas mahasiswa Aspek-aspek aktivitas belajar mahasiswa antara lain keantusiasan mahasiswa dalam mengikuti proses pembelajaran di kelas, keberanian mahasiswa dalam bertanya, ketekunan mahasiswa dalam menyelesaikan tugas yang diberikan guru, dan kerjasama mahasiswa dalam kelompok. Data aktivitas belajar mahasiswa siklus II dapat dilihat pada tabel berikut ini. Tabel 4.6 Aktivitas Belajar mahasiswa Siklus II 52 No. Aspek yang dinilai Rata-rata persentase aktivitas Pertemuan 3 Pertemuan 4 1. Keantuasiasan mahasiswa dalam mengikuti proses pembelajaran di kelas $86.36 \%$ $96.59 \%$ 2. Keberanian mahasiswa dalam bertanya 75\% 78.41\% 3. Ketekunan mahasiswa dalam menyelesaikan tugas yang diberikan guru 92.05\% 100\% 4. Kerjasama mahasiswa dalam kelompok 93.18\% 100\% Rata-rata persentase aktivitas $86.65 \%$ 93.75\% Rata-rata persentase aktivitas siklus II $90.20 \%$ Aspek keberanian mahasiswa dalam bertanya pada pertemuan ketiga yaitu $75 \%$ dan pada pertemuan keempat $78.41 \%$. Aktivitas pada pertemuan ketiga yaitu $86.65 \%$ dan aktivitas pada pertemuan keempat 93.75\% maka rata-rata aktivitas siklus II yaitu $90.2 \%$.

\section{DAFTAR PUSTAKA}

Acep Yonni, dkk. 2010. Menyusun Penelitian Tindakan Kelas. Yogyakarta: Familia.

Achmad Sugandi, dkk. 2007. Teori Pembelajaran. Semarang: UPT MKK UNNES.

Bahari, Nooryan. 2008. Kritik Seni Wacana, Apresiasi dan Kreasi. Yogyakarta: Pustaka Pelajar.

Bastomi. Suwaji. 2003. Kritik Seni. Semarang: UNNES Press.

BSNP. 2006. Standar Isi Untuk Satuan Pendidikan Dasar dan Menengah. Jakarta: Depdiknas.

BSNP. 2007. Pedoman Penilaian Hasil Belajar Di Sekolah Dasar. Jakarta: Depdiknas.

Catharina Tri Anni, dkk. 2007. Psikologi Belajar. Semarang: UPT MKK UNNES.

Dimyati dan Mudjiono. 1999. Belajar dan Pembelajaran. Jakarta: Rineka Cipta.

Garha. Oho. 1980. Pendidikan Kesenian Seni Rupa. Jakarta: Departemen Pendidikan dan 
Kebudayaan.

Hamalik, Oemar. 2007. Kurikulum dan Pembelajaran. Jakarta: PT Bumi Aksara.

Hadjar Pamadhi, dkk. 2010. Pendidikan Seni Di SD. Jakarta: Penerbit Universitas Terbuka

Jools, Tessa dan Denise Grande. 2005. A Case

Study in Elementary School Media Literacy and Arts Education. Project SMARTArt. 25-30.

Lee, Alan. 2009. Art Education and The National Review of Visual Education. Australian journal of Education. 218.

Iswidayati, Sri. 2010. Pemanfaatan Media Pembelajaran Seni Budaya. Semarang: UNNES Press.

Mariamah, Fifi Faridah, Ratnah \& Suratman. (2015). Faktor-Faktor Yang Mempengaruhi Mahasiswa STKIP Taman Siswa Bima Menggunakan Jasa Konsultan Dalam Penyusunan Skrispsi Tahun Akademik 2015. Jurnal MIPA vol. 6 no.2

Peraturan Pemerintah Republik Indonesia Nomor 19 Tahun 2005 Tentang Standar Nasional Pendidikan. 227 Sadiman, Arief S. 2009.

Media Pendidikan. Jakarta: Rajawali Pers. Sahman, Humar. 2003. Mengenali Dunia Seni Rupa. Semarang.

IKIP Semarang Press. Saminanto. 2010. Ayo Praktik PTK: Penelitian Tindakan Kelas.

Semarang: RaSAIL Media Group. Sobandi, Bandi. 2008.

Model Pembelajaran Kritik dan Apresiasi Seni Rupa. Bandung: UPI Press. Stone, Sandra J. dan Basanti Chakraborty. Proses Art vs. Product Art: The Theacher's

Dilemma. Sudjana, Nana. 2010. Dasar-Dasar Proses Belajar Mengajar. Bandung: Sinar Baru Algesindo.

Sugiarto, Eko. 2011. Peningkatan Kemampuan Apresiasi Lukisan Berbasis Kritik Menggunakan Media Pembelajaran Appreciation Card Bagi Siswa Kelas IX B SMP N 2 Kudus. Skripsi. Universitas Negeri Semarang.

Sugiono. 2008. Metode Penelitian Pendidikan. Bandung: Alfabeta. Sugono, Dendy. 2008. Kamus Bahasa Indonesia. Jakarta: Pusat Bahasa Depdiknas.
Suharsimi Arikunto, dkk. 2009. Penelitian Tindakan Kelas. Jakarta: PT Bumi Aksara. Suprayekti, dkk. 2009. Pembaharuan Pembelajaran Di SD. Jakarta: Universitas Terbuka.

Thobroni, Muhammad dan Arif Mustofa. 2011. Belajar $\mathcal{E}$ Pembelajaran. Jogjakarta: Ar-Ruzz Media. Undang-Undang Republik Indonesia Nomor 14 Tahun 2005 Tentang Guru dan Dosen. Undang-Undang Republik Indonesia Nomor 20 Tahun 2003 Tentang Sistem Pendidkan Nasional. Zainal Aqib, dkk. 2010. Penelitian Tindakan Kelas Untuk Guru, SD, SLB, TK. Bandung: CV Yrama Widya. 